\title{
5 Public and Private Wrongs
}

\author{
R A Duff and S E Marshall
}

\author{
A. SHARING WRONGS \\ B. VICTIMS AND PERPETRATORS \\ C. PUBLIC WRONGS AND THE CRIMINAL LAW \\ D. CRIMINAL AND CIVIL PROCEEDINGS
}

\section{A. SHARING WRONGS}

Gordon's Criminal Law begins, as textbooks on criminal law often and naturally begin, by seeking a definition of "crime". After a brief but incisive discussion, he concludes that only a formal (and far from precise) definition is possible: ${ }^{1}$

The criminal law is probably, therefore, sufficiently defined as that branch of the law which deals with those acts, attempts and omissions of which the state may take cognisance by prosecution in the criminal courts.

His concern here is, of course, descriptive or analytical rather than normative: the aim is not, that is, to define what should be criminal, with a view to guiding legislators in deciding what to criminalise; it is rather to enable those who would study the criminal law of Scotland to identify the subject of their study. From that point of view, a formal definition is the most we can hope for, and Gordon's essentially procedural definition has significant merits; we will say more later, in particular, about the importance of focusing on the process of prosecution and on the state as prosecutor. Our concern, however, is normative rather than descriptive or analytic: it is with the question, not of how we can identify what is criminal, of what now falls within the scope of the criminal law, but of how legislatures and polities should set about deciding what ought to be criminalised.

- We are grateful for comments on a draft of this chapter received at the conference in honour of Sir Gerald Gordon, but above all to Sir Gerald himself, whose work offers as much insight and stimulation to philosophers of law as it does to practically-minded lawyers.

1 G H Gordon, The Criminal Law of Scotland, $2^{\text {nd }}$ edn (1978) $15 ; 3^{\text {rd }}$ edn vol 1 (2000) at 7. 
We have argued elsewhere that this large normative question can be best approached by reviving, and somewhat revising, the classical idea that crimes are "public wrongs": 2 if we are to justify criminalising a certain type of conduct, we must show that it constitutes what can properly be classed as a public wrong. We will not say more here about the claim that crimes must be wrongs: we take it for granted that the criminal law is a censuring practice, which defines certain kinds of wrong and provides for their perpetrators to be called to account, condemned and punished. ${ }^{3}$ But not all wrongs are even in principle criminalisable: the chief error of traditional Legal Moralism, according to which the proper aim of criminal law is to condemn and punish wrongdoing, ${ }^{4}$ is not that it focuses on wrongdoing as the proper concern of the criminal law, but that it takes all wrongdoing, of any and every kind, to be in principle the business of the criminal law. We must distinguish "public" wrongs, which are - at least in principle - the criminal law's proper business, from "private" wrongs that are "in brief and crude terms, not the law's business". The question then, of course, is what "public" means in this context.

On one kind of account, which was Blackstone's, a wrong is public if it wrongs or harms "the public", the polity as a whole, as distinct from any individual victim. Now there are such wrongs, wrongs that injure what are essentially shared or public goods (environmental goods such as clean air, for example); but if we take this to be the defining feature of everything that is to be legitimately criminalised, we will have to search for such a wrong at the core of every crime, which will lead us to distort the criminally wrongful character of some familiar mala in se. What makes rape and murder criminal, what justifies or demands the attention of the criminal law, is not that the murderer or rapist harms or wrongs the public at large, but what he does to his individual victim: if we are to give the victims their due, the criminal law's attention must be on the wrongs that they have suffered. A better understanding of the idea of a public wrong is, we suggest, that it is a kind of wrong that properly concerns "the public" - a wrong that is a matter of public interest in the sense that it properly concerns all members of the polity by virtue simply of their shared membership of the political community. The wrong that merits criminalisation, the wrong for which a wrongdoer is called to account, condemned and punished by the criminal law, is the wrong that

2 See, classically, Blackstone, Commentaries Bk IV ch 1.

3 See R A Duff, Answering for Crime (2007) ch 4.

4 See e.g. M S Moore, Placing Blame (1997) ch 1.

5 Report of the Committee on Homosexual Offences and Prostitution (Cmnd 247: 1957) para 61. 
he does to his individual victim; but it is a wrong in which we share as fellow members of the political community to which wrongdoer and victim belong, ${ }^{6}$ and a wrong to which we must therefore respond collectively. The wrong committed by a husband who beats up his wife might be "private" in the sense that it occurs within the home, and has no material impact on the wider social world; but it is - as we now recognise - a public wrong in the sense that it is one that should concern us all, and that should not be left to the couple to sort out for themselves as a merely domestic affair. ${ }^{7}$

That is why, as Gordon's definition emphasises, the process of prosecution is crucial to the idea of crime. One who commits a public wrong is properly called to public account for it, and the criminal trial constitutes (in ideal theory, if all too obviously not in actual practice) such a public calling to account. The state is the proper prosecutor of crimes: since a crime is "our" wrong, rather than only the victim's wrong, it is appropriate that we should prosecute it, collectively. The case is not simply $V$ the victim, or $P$ the plaintiff, against $D$ the defendant; it is brought, as the Americans properly have it, by "the People", or by "the Commonwealth", against the defendant. ${ }^{8}$

This is, we still believe, a useful way in which to think about crimes and criminalisation; in the remainder of this chapter, we will try to develop this conception of public wrongs a little further, which will also involve complicating it more than a little. (A developed account of the kind we are suggesting will of course require more underpinning by political theory than we can provide here. We work from a version of liberal communitarianism that rejects the metaphysical version of the individualist's "unencumbered self"; but the account that we sketch here should be compatible with all but the most radically individualist kinds of liberal theory.)

\section{B. VICTIMS AND PERPETRATORS}

One issue that we should note, though we cannot pursue it in detail here, concerns the status of the offender. We have focused so far on the idea that we share in the victim's wrong: it is his wrong, as an attack on him, but is

6 The criminal law also, of course, both binds and protects temporary residents of or visitors to a polity, as well as its citizens: its paradigmatic concern, however, is with the polity's citizens and their dealings with each other (see Duff, Answering for Crime (n 3) ch 2.2).

7 For this argument, see S E Marshall and R A Duff, "Criminalization and sharing wrongs" (1998) 11 Canadian Journal of Law and Jurisprudence 7; S E Marshall and R A Duff, "Communicative punishment and the role of the victim" (2004) 23 Criminal Justice Ethics 39.

8 See further R A Duff, L Farmer, S E Marshall, V Tadros, The Trial on Trial (3): Towards a Normative Theory of the Criminal Trial (2007). 
also our wrong because he is one of us. That is what makes it proper, and perhaps morally necessary, for us to respond collectively not just to him as a victim (to offer sympathy and support), but also to the wrongdoer - to call the wrongdoer to public account for what she has done. However, we must also remember that when a crime is committed by one citizen against another, the offender is also one of us; so should we also say that we share in his wrong(doing), as we share in the victim's wrong (suffering)?

It is certainly important that we see the offender, and that the criminal process of trial and punishment treat the offender, not as an outsider or an enemy, but as a fellow member of the normative community that is partly defined and constituted by the criminal law. The language of penal policy, and the impact of our penal practices, is all too often exclusionary: "we", the law-abiding, must be protected against "them", the criminals; and what is then done to "them" in the name of the "war on crime" all too often serves to reinforce their exclusion from civic society. But if the criminal law is to be a properly common law, if it is to be the law of the whole polity (and so our law as members of the polity), it must be inclusive, not exclusive: it must address and treat all citizens, including those who offend, as members of the normative community. One of the key challenges for penal policy and practice, and for the citizens in whose name penal policy is formulated and put into practice, is to make that idea of inclusion something more than a rhetorical flourish: how can the institutions of the criminal law, and in particular our penal institutions, treat offenders as fellow citizens, whilst still taking their crimes seriously as wrongs? One point worth stressing in this context is that an important aspect of taking one another seriously as citizens is precisely that we pay attention to wrongs that we commit; this is one way in which we acknowledge each other as responsible agents. ${ }^{9}$ Now in some kinds of community, members of the community share the wrongs done by fellow members in a deeper way than this: not only do we respond to you as a fellow member who has done wrong, we are collectively embarrassed, even shamed by that wrong, just because it was committed by one of us. This kind of response is perhaps most familiar, most easily understood, in the context of such small and relatively intimate (and all-embracing) communities as families: given a certain conception of the family, wrongs committed by one member are understood as wrongs that reflect badly on the whole

9 This illustrates the way in which criminal law theory must draw not just on political theory, for an account of the proper relationships between state and citizen and between citizens, but also on moral theory, for an account of what it is to treat others as responsible agents. 
family and bring shame to its other members. ${ }^{10}$ It is also possible within small communities that, whilst not intimate or all-embracing in the way that families can be, are defined by a firm, shared commitment to a substantial normative project: an academic department, for instance, which defines itself by a shared commitment to certain ideals of scholarship and education, might feel collectively shamed or demeaned by the academic misdeeds of one of its members; those misdeeds injure the department's moral character (as well as its reputation), in which all its members share. Citizens can in a similar way feel ashamed of the actions of their governments, or of other official or quasi-official representatives of the polity: even if I did not vote for these people, and have vigorously opposed their policies and actions, they still act in my name. One can even feel ashamed of one's nation's historical misdeeds, though there are interesting questions about how far into the past such shame can intelligibly reach: could it really make sense, for instance, for the English to feel ashamed of the Crusades? But does it make sense for the citizens of a modern liberal state to respond in this way to the criminal wrongs committed by others whose only connection to them is that of citizenship? Or would such a sharing of wrongs make sense only from the perspective of the kind of oppressively embracing communitarianism that liberals rightly resist?

Even if, as we think is probably so, such intimate sharing of wrongs is alien to the kind of liberal polity in which we live (or hope to live), the question of whether or in what ways we should see ourselves as sharing, as fellow citizens, in the offender's wrong points us towards other possibilities - other ways in which we might recognise some responsibility for or in relation to the wrongs committed by our fellow citizens. That responsibility might sometimes be retrospective: we need at least to ask ourselves (as critical theorists of various kinds insist that we must ask) how far our collective responsibility for the social, political and economic conditions from which so many crimes emerge - conditions in whose maintenance those who benefit from them are at least complicit - makes us partly responsible for those crimes (which need not imply that the offenders' responsibility is thereby reduced). More interestingly, it might be prospective: whether or not we should hold ourselves retrospectively responsible for crimes that have been committed, a recognition of the offender as a fellow citizen might bring with it recognition that we have a collective responsibility to help to provide an appropriate response to the crime. That response will focus in part on the victims (when there

10 For a dramatic literary working out of this phenomenon, see Balzac's Cousin Bette (1846), in which the misdeeds of Baron Hulot D'Ervy also bring destruction to his family, especially his wife and brother. 
are direct victims) as something that we owe to them as our fellows, but will also focus on the offender: we owe it to him to try to bring him to recognise, and to see the need to make moral reparation for, what he has done - rather than, for instance, treating him as an enemy or an outsider. This does not preclude a criminal process of trial and punishment; but it demands that the process treat the offender as a citizen who is still a full member of the political community.

There is, clearly, much more to be said about the sense in which we can be said to share in the criminal wrongs committed by our fellow citizens, and about the implications of such sharing, but we cannot embark on a full development of this idea here. We will instead, as a way of drawing out some of what it might involve, focus on the relationship between public wrongs, as that idea is understood here, and the criminal law. We will also consider the question of whether the criminal law (or criminal law as we know it) is always the appropriate way to respond to such wrongs.

\section{PUBLIC WRONGS AND THE CRIMINAL LAW}

The criminal law, we have suggested, is properly concerned with public wrongs: that is, with wrongs that are properly the business of all citizens simply in virtue of their membership of the polity whose law it is. This does not, of course, help us to determine which wrongs should count as public which kinds of wrong we do have good reason to criminalise; that a wrong is in this sense a public wrong does not so much ground as express the claim that it is one that could in principle be legitimately criminalised. Nor, which is more germane to our present purposes, is this to say that we should criminalise all public wrongs: it is at most to say that we have some good reason to criminalise such wrongs - which leaves open the possibility that we have even better reasons not to criminalise many such wrongs. ${ }^{11}$ In this section we will explore some such reasons, and some alternatives to criminalisation.

Given our existing legal institutions, criminalisation has several separable dimensions. First, to criminalise a type of conduct is to make its purported wrongfulness salient: ${ }^{12}$ it is to focus on its wrongful character, on the need

11 Compare J Schonsheck, On Criminalization: An Essay in the Philosophy of the Criminal Law (1994) on the stages or "filters" through which decisions about criminalisation should proceed.

12 Its purported, rather than its actual, wrongfulness because the claim that the criminal law is focused on wrongs does not imply (absurdly) that it is impossible to criminalise conduct that is not wrongful: it implies only that if we are to justify criminalising a type of conduct, we must at least argue that it is wrongful (see V Tadros and S Tierney, "The presumption of innocence and the Human Rights Act" (2004) 67 MLR 402). 
to call its perpetrators to account and to condemn what they have done, as what is important about it. That is not to say that we cannot also try to deal with, for instance, the material harm that the criminalised conduct might cause - that we cannot or should not seek to prevent such harm, or to repair it when it is caused. However, such concerns are not the particular business of the criminal law, or the grounds for criminalising the conduct. Second, to criminalise conduct is to take it out of the hands of the victim and of others closely involved with it, into the formal structures of the criminal process: to treat the conduct as criminal is to treat it as conduct that should be dealt with, not through the informal responses of those close to it, but through the formal activities of criminal justice officials and procedures. This point is illustrated most vividly by the fact that whether a criminal case is to proceed is not, formally, a matter for the (alleged) victim to decide: the prosecutor can decide not to bring the alleged offender to trial, even if the alleged victim demands it, or can decide to bring the case to trial even if the victim would prefer to see it dropped. ${ }^{13}$ Third, to criminalise conduct is to make its perpetrators liable not merely to condemnation in court, or to pay compensation for such harm as they might have caused, but to criminal punishment - to the imposition of some measure that is intended to be burdensome.

One question that arises is whether all public wrongs, all wrongs that properly concern members of the polity simply by virtue of that membership, are such as to warrant a response that has these three dimensions. Or should we instead say that the criminal law is properly concerned only with some kinds of public wrong, whilst others can be either ignored (as far as any formal process is concerned) or dealt with by other, non-criminal, means? A further, related question, to which we return below, is whether the three dimensions noted above must be linked as they are in our existing institutions: or could we (and should we) develop new procedures that separate them - so that, for instance, certain kinds of crime could make their perpetrators liable to conviction but not to punishment; or so that victims could be formally allowed to decide whether "their" wrongdoers are brought to court (or even to bring the cases themselves)?

In relation to the first question, it is worth noticing the variety of ways in which a polity can decriminalise, or avoid criminalising, conduct that passes the first criminalisation test - conduct that constitutes a public wrong, which

13 Very often, prosecutors will, for a variety of reasons, not proceed with a case if the victim is unwilling, but victims have no formal right to bar the prosecution from proceeding. For an interesting discussion of this issue, and of why prosecutors might proceed in cases of domestic violence despite the unwillingness of the victim, see M M Dempsey, Prosecuting Domestic Violence: A Philosophical Analysis (2009), especially chs 8-9. 
there is therefore reason to criminalise. We cannot discuss all these ways here, but should note the most interesting ones.

First, we could leave such conduct entirely outside the reach of law, so that any response to it by the wrongdoer's fellow citizens will be extra-legal and informal. Thus if, for instance, we adopt a robust de minimis principle, ${ }^{14}$ as we surely should, we will recognise a range of public wrongs (minor acts of public rudeness or incivility, for instance) that are just too trivial to be criminalised, or indeed subjected to any kind of formal legal response.

Second, we could subject the conduct to a non-criminal regime of legal regulation and sanction: we could, following the German model, make it an Ordnungswidrigkeit rather than a Straftat. ${ }^{15}$ An Ordnungswidrigkeit is a breach of the law (it is "rechtswidrig"), but it is not defined in terms of the kind of guilt or fault ("Schuld") that warrants condemnation, and it is subject only to a non-custodial penalty - typically an administrative fine (Geldbusse), which is formally distinguished from a criminal fine (Geldstrafe). Whereas criminal law condemns and punishes wrongs, this kind of administrative or regulatory law penalises violations; ${ }^{16}$ its most plausible aim is simple deterrence.

Third, with conduct that involves some actual or alleged harm to other people's interests, we could make it a matter of civil rather than of criminal law: we could provide procedures through which the (alleged) victim could sue the (alleged) wrongdoer for compensation, so that as far as possible the cost of the harm falls on the person who culpably caused it.

Fourth, for conduct that creates or arises from a dispute between citizens, we could make provision for mediation or negotiation, rather than subjecting it to direct regulation: citizens could be enabled or encouraged to seek the services of a state-appointed or state-authorised mediator or arbitrator, who would help them to resolve their dispute and find a more peaceful way of living as fellow citizens. We could, that is, treat the wrongs as conflicts to be

14 Compare Model Penal Code $\$ 2.12$ (defining a “de minimis" defence); and see D Husak, “The de minimis 'defense' to criminal liability”, in R A Duff and S P Green (eds), Philosophical Foundations of Criminal Law (forthcoming).

15 See Gesetz über Ordnungswidrigkeiten (1968/1975). The transfer of certain kinds of conduct from the criminal law properly speaking (the Strafgesetz) to the category of Ordnungswidrigkeiten was explicitly portrayed as a species of decriminalisation in Öztürk v Germany (1984) 6 EHRR 409, though the court held that this kind of formal reclassification did not exclude the defendant from the protections of article 6 of the ECHR. For critical discussions, see T Weigend, "The legal and practical problems posed by the difference between criminal law and administrative penal law" (1988) 59 Revue Internationale de Droit Pénal 67; Duff et al, The Trial on Trial (n 8) ch 6.5 .

16 Compare J Feinberg, “The expressive function of punishment”, in his Doing and Deserving (1970) 95, on the difference between "punishments" and "penalties". 
resolved rather than as crimes to be punished. ${ }^{17}$

Fifth, if our primary concern is to prevent conduct that is seen as dangerous or disruptive, and if we think that purely responsive, sanctionbased measures are unlikely to be effective enough, we might look to such pre-emptive measures as control orders - measures (which are themselves often backed by the threat of criminal punishment for their breach) to restrict the freedom of those judged likely to engage in such conduct. ${ }^{18}$

Finally, a quite different method of decriminalisation relies on officials' exercise of their discretion. Thus a police force might make it a policy not to bring charges, or to take any kind of action, in relation to certain types of conduct that are formally criminal (the possession of small quantities of a prohibited drug, for instance); or a prosecuting authority might follow - and indeed announce publicly - a policy of not prosecuting some kind of conduct that is formally criminal. ${ }^{19}$

Each of these methods of de- or non-criminalisation raises problematic questions; some, such as various kinds of preventive order, are controversial in themselves. We cannot discuss most of them here, and list them only to emphasise the complexity of the question of whether or not a given type of conduct should be criminalised, even if we agree that it constitutes a public wrong, and even if we agree that it should be subject to some kind of legal regulation or control: for we have still to decide which of a range of possible kinds of legal provision, of which criminalisation is just one, should be applied. That decision will be partly guided, no doubt, by considerations of cost and efficacy, but should also be guided by considerations of intrinsic appropriateness: given the nature of the wrong that the conduct involves, what kind of formal, official response would be appropriate? In particular, given the defining features of the criminal law noted above, which kinds of

17 Compare the proposals made by advocates of "restorative justice" who urge us to create mediation processes that aim to repair harm and resolve conflicts or troubles rather than to punish supposed wrongs. See, classically, N Christie, "Conflicts as property" (1977) 17 British Journal of Criminology 1; L Hulsman, "Critical criminology and the concept of crime" (1986) 10 Contemporary Crises 63. For critical discussions, see A von Hirsch et al (eds), Restorative Justice and Criminal Justice (2003).

18 For a useful critical survey of such preventive measures, see A J Ashworth and L Zedner, "Preventive orders: a problem of undercriminalization?”, in R A Duff, L Farmer, S E Marshall, M Renzo, and V Tadros (eds), The Boundaries of the Criminal Law (forthcoming).

19 As the English Director of Public Prosecutions has now effectively done (following $R$ (ex parte Purdy) v DPP [2009] UKHL 45, [2009] 3 WLR 403), in issuing guidelines about the factors to be taken into account in decisions about whether to prosecute in cases of assisted suicide: see $w w w$. cps.gov.uk/publications/prosecution/assisted_suicide_policy.html. The exercise of official discretion in applying criminal law is especially important in the area of corporate regulation in matters of health and safety: see e.g. B Fisse and J Braithwaite, Corporations, Crime and Accountability (1994). 
wrong are such as to make appropriate a formal response that makes their wrongful character salient, that calls their perpetrators to answer not just to their individual victims but to the polity as a whole, and that condemns and punishes those perpetrators?

However, the question of criminalisation becomes yet more complex once we recognise that the three defining features of criminal law, while they coincide in our own legal systems, are separable, for this opens up the possibility of different modes of criminalisation. We can illustrate some of these possibilities by focusing on the contrast between criminal and civil law as two kinds of legal response to, or provision for dealing with, public wrongs.

\section{CRIMINAL AND CIVIL PROCEEDINGS}

The distinction between civil and criminal law in our actual systems is of course neither clear nor sharp, but we can identify two paradigms - of a criminal law process and of a civil law process.

The criminal paradigm was sketched earlier. A criminal case is brought and controlled by the polity as a whole (by the state, acting as the polity's agent), not by the individual victim of the wrong; it is focused on the (alleged) wrong for which the (alleged) perpetrator is called to answer in court; its outcome, if the allegation is proved, is condemnation and punishment. By contrast, under the civil law paradigm, the case is brought and controlled by the plaintiff (often an individual, sometimes a collective) who claims to have suffered harm or loss: it is up to her whether to bring the case, whether and how far to proceed with it, whether and on what terms to settle it without going to court, and whether to seek to enforce any judgment in her favour. The focus of the case is on the harm or loss that the plaintiff claims to have suffered (or to be likely to incur) through the defendant's fault; and its outcome, if the plaintiff wins, is that the defendant is held liable to repair or to pay for the repair of the harm (if it can be repaired), or to pay compensation that will at least ameliorate the effects of that harm. ${ }^{20}$ To put the matter simply, a criminal case is concerned with who is answerable, and punishable, for a wrong (even if, for those who accept some version of the Harm Principle, it must be a harmful wrong), whereas a civil case is concerned with who should

20 There are difficult questions, which we cannot pursue here, about the limits of reparation or compensation - about kinds of harm, or kinds of wrong, for which nothing could count as complete or adequate compensation, and about kinds of harm or wrong for which a monetary payment (the typical outcome of a civil case) is not merely inadequate, but intrinsically inappropriate: see R E Goodin, "Theories of compensation", in R Frey and C Morris (eds), Liability and Responsibility (1991) 257. 
have to pay to avert, to repair or to ameliorate some harm (even if, for those who eschew strict civil liability, it must be a wrongful harm).

Given these two paradigms, we can bring together two familiar complaints, one about the criminal law and one about civil law. The complaint against the criminal law is, as expressed (over-)dramatically by Nils Christie, that it "steals" our conflicts: it takes the "conflict" that, in Christie's eyes, crime involves away from those whom it directly concerns, into the formal, professional world of the law, thus depriving them of the chance to deal with it themselves. ${ }^{21} \mathrm{~A}$ less dramatic, less misleading version of this kind of objection is that the procedures of the criminal law tend too easily to exclude victims from having any real say in, or any control over, what happens to "their" cases or "their" offenders. Part of the point of calling criminal wrongs public wrongs is of course precisely to insist that they are not (merely or only) the victims' wrongs, but we might still worry that our existing criminal process implicitly denies that the wrongs with which it deals are even partly the victims' wrongs.

The complaint against the civil law is that it requires those who want to seek redress, or apology, for wrongs that they have suffered to do so by claiming monetary compensation for harm allegedly caused to them by those wrongs - a kind of claim that inevitably distorts the character of their concern. One sad example of this is provided by parents who sue the doctor or hospital whose negligence they blame for the death of a child, and who might complain, if they win their case, that the sum awarded by the court in damages undervalues their child. ${ }^{22}$ Such complaints are both reasonable and unreasonable: unreasonable because they imply that some much larger sum might have been adequate compensation for their loss, but reasonable because monetary compensation does not address what they have suffered. What they want is (quite reasonably) that those who were responsible for the wrong (the wrong of negligence) done to their child and through their child to them should have to answer for that wrong in a suitable public forum, but a claim for monetary compensation - a claim that looks to a harm rather than to a wrong - is all that the law makes available to them.

Perhaps we could try to meet both these kinds of complaint about the existing operations of our criminal and civil procedures by some modest re(or de-)construction of the criminal law paradigm. One possibility would be to extend and adapt the existing, infrequently used, provisions for private 
criminal prosecutions: ${ }^{23}$ to specify a category of criminal offences (and perhaps create some new ones: to deal, for instance, with cases of medical negligence) which can be prosecuted only by the alleged victim, and also to provide appropriate post-conviction disposals that focus on the wrong done rather than any harm caused (perhaps formal apology, or an analogue of community service directed towards the victim). Such privately prosecuted crimes would still count as public wrongs: they would be defined as wrongs by the law, and the law would provide a forum in which their victims can seek satisfaction (and would determine what would count as adequate satisfaction). But they would be wrongs that the polity did not insist on sharing in the way that it now insists on sharing criminal wrongs: it would support victims who wished to pursue their wrongdoers, but would not insist on taking over that pursuit.

There are obvious objections to such a suggestion. One is that unless private prosecutions were subject to some kind of official control or veto, it would open the way to frivolous or utterly ill-founded prosecutions that would unreasonably burden their targets (although that is of course no less and no more a possibility with private civil law suits). Another is that without a system of legal aid far better resourced and far more widely available than seems likely in the foreseeable future, it would favour wealthy victims, and would further disadvantage those without the substantial means required to pursue their cases, or without the confidence or the understanding required even to think of bringing a case. We might still find a small place for such privately prosecutable wrongs, given an improved system of legal aid, but they would be unlikely to take over much of the existing criminal law.

Alternatively, we could give victims a larger formal say in the prosecution process. The law could provide, for instance, that certain kinds of crime should be prosecuted by the public prosecutor, but only at the victim's request, ${ }^{24}$ while others should be prosecuted only with the victim's consent (we cannot pursue the important distinction between request and consent further here). That would leave two kinds of case in which individual victims would not have any formal control over the prosecution: those in which the only victim is "the public", in which the decision would need to rest solely with the public prosecutor; and those in which although there is an individual victim, the prosecutor could decide to pursue the case with or without the

23 Which in Scotland require the consent of the Lord Advocate or the High Court of Justiciary, and in England can be taken over and dropped by the Director of Public Prosecutions.

24 Which is not of course to suggest that the victim's request should be a sufficient condition for prosecution. 
victim's consent, because it involved a kind of wrong that must be condemned, and whose perpetrator must be called to account. The latter kind of case would constitute the hard core of the criminal law, in which only a formal criminal-law response is adequate. The question then, of course, would be what kinds of wrong (if any) are of this kind, and why. A tempting answer might be that only those wrongs that also somehow threaten "the public" fall into this category, ${ }^{25}$ but we are not sure that that is right: if we are to do justice to the victims of crime, and to the character of the wrongs that the criminal law must condemn, our attention must remain focused on what was done to them, not on its possible further implications for the wider public.

Much more work would be needed than we can undertake here to develop the details of this kind of suggestion, or to work out just how the criminal law could best give victims more of a say in the prosecution (or non-prosecution) of those who wrong them. The suggestion is, it should be noted, quite different from those made by advocates of "restorative justice", who would remove what are now criminal cases from the formal criminal process altogether, to a more informal process of mediation that would be controlled by those (victims, offenders, their families or friends and supporters) most directly involved in the "conflict": ${ }^{26}$ our aim is to preserve the formality and authority of the criminal law, as defining the kinds of wrong that merit condemnation by the polity, and as providing an appropriate forum in which those who commit such wrongs can be called to answer for them. Our suggestion is not that we should look for informal, non-criminal ways of responding to some kinds of wrong, even some kinds of public wrong (though we have no doubt that we should sometimes do that), but that within the institutions of the criminal law itself, within the formal procedure of the criminal trial, we should find ways of giving victims more of a say in what happens.

What lies behind this suggestion is the thought that not all wrongs categorically require a condemnatory response that calls the wrongdoer to account. Outside the law, we recognise three kinds or categories of wrong. There are, first, those that are too trivial to be worth pursuing very far: some brief complaint or criticism might be in order, but to insist on calling the offender to account, to dwell on the wrong, would be excessive. Second, there are wrongs which it would be reasonable for the wronged party to pursue, but which she might also quite reasonably shrug off as relatively unimportant.

25 Compare the account offered in J Gardner and S Shute, "The wrongness of rape", in J Horder (ed), Oxford Essays in Jurisprudence: Fourth Series (2000) 193, of the kind of harm that makes rape properly criminalisable.

26 See R A Duff, "Restoration and retribution", in A von Hirsch et al (eds), Restorative Justice and Criminal Justice (2003) 43. 
Had she wanted to pursue it, we (her friends, her colleagues) would of course have supported her, but we can respect her view that it is not worth pursuing, and perhaps even admire the strength of character or the lack of egoism that her response displays. Third, there are wrongs that the victim ought to pursue, that it would be wrong to shrug off or ignore; she might be disinclined to pursue it, but (we would say) that response is now wrong or unreasonable. In the third kind of case we (as her friends, her colleagues) would see reason to pursue the wrong and the wrongdoer even if the victim asked us not to perhaps not a conclusive reason to override her wishes, but certainly a reason that is not negated or undercut by her preference. Our suggestion here is that the criminal law should reflect these distinctions, by distinguishing three categories of public wrong. The first category is covered by the de minimis principle: these wrongs are too trivial to merit the law's attention at all. The second category is that in which the victim should have formal control over whether a prosecution is brought - either through a system of private prosecutions or, as we suggested above, by allowing a prosecution to proceed only at the victim's request or only with the victim's consent. The third category is that in which, as now, the victim has no such formal control: the prosecution can go ahead with or without the victim's consent.

The key question about this kind of structure is, of course, how we are to distinguish the second category from the third: how should we identify those wrongs for which a formal criminal response is necessary - those wrongs that the polity must condemn if it is to remain true to itself? ${ }^{27}$ It is obviously, in part, a matter of the seriousness of the wrong, but it is not clear that it is simply a matter of seriousness on a linear scale; nor is it clear either how we should assess seriousness, or why some wrongs should be pursued even without the victim's consent. We have space only to note two points by way of initial approach to these issues.

First, in so far as the distinction between the second and third categories does depend on the seriousness of the wrong, we need to ask whether and in what ways the victim's response to the wrong conditions its seriousness. Consider, for instance, a campaign of racist insults directed against a member of a minority group, intended to humiliate him. Suppose that he is strong and self-confident enough to shrug the insults off, and to regard the insulters with contempt or pity rather than with fear: should we now say that the wrong done to him is a much less serious wrong than it would have been had the insults had their intended impact? Or that the wrong done is just the same,

27 For some suggestive remarks on this, see N Jareborg, "Criminalization as last resort (ultima ratio)" (2005) 2 Ohio State Journal of Criminal Law 521. 
although luckily in this case it does not cause the kind of harm that it was intended, and might have been expected to do ${ }^{28}$ When and to the extent that the seriousness of the wrong does depend in this kind of way on the victim's response to it - on whether the victim regards and responds to it as a serious wrong - we have reason to place it in the second category, and so to allow a prosecution only if the victim requests or consents to it.

Second, there seem to be two ways of explaining the suggestion that some wrongs ought not to be, or cannot be, shrugged off, but must be pursued. One explanation focuses on the victim, and on the idea that he owes it to himself to take the wrong seriously and to respond to it: a failure to respond with anger and indignation, and to seek prosecution, would display a lack of proper selfrespect. ${ }^{29}$ This idea certainly has force in our extra-legal moral thinking, but it is not clear how much work it can do in explaining why criminal prosecutions should sometimes go ahead even without the victim's consent: it would be a stringent (and probably ineffective) kind of moral paternalism that authorised the state to act in this way on the basis of the respect that a victim ought to have for himself.

A second explanation is not thus paternalistic, since it focuses on what the victim owes not to himself, but to others, and on his responsibilities as a citizen. He owes it to his fellow citizens, we might now say, to pursue the wrongdoer: not, or not necessarily, for the kinds of consequentialist reason to which some would appeal (the need to convict the offender before he re-offends against others, for instance), but because not to pursue the wrongdoer would be to betray the defining values of the polity to which we all belong. ${ }^{30}$ This is more promising as an explanation of why the polity should insist on prosecuting (rather than of why the victim's friends might urge him to pursue the wrongdoer, which is where the first kind of explanation fits more happily). However, it obviously raises some large and serious questions, which we cannot pursue further here, about the responsibilities or duties (as well as the rights) that we should ascribe to the victims of crime. Can we say, for instance, that the victim of a serious crime has a duty to bear witness to

28 This question is clearly related to the notoriously controversial question of whether the success or failure of a criminal attempt can affect, not the culpability of the agent, but the seriousness of the wrong for which he is to be condemned and punished.

29 Compare Murphy's discussions of the role and importance of resentment, e.g. in J G Murphy, "Forgiveness and resentment", in J G Murphy and J Hampton, Forgiveness and Mercy (1988) 14; and J G Murphy, Getting Even: Forgiveness and its Limits (2003), esp ch 2.

30 The issue of prosecuting domestic violence even without the victim's consent provides a good test case here (if the reasons for thus insisting on prosecution do not have to do simply with the victim's supposed incapacity to decide the matter rationally for herself): see Dempsey, Prosecuting Domestic Violence (n 13). 
the crime, and so to engage with the criminal process? If so, is that duty of the same kind as the duty of any citizen to assist in the prosecution of a crime that she has witnessed; or is the victim's duty a special one, by virtue of the distinctive witness that she can bear? (To say that the victim has such a civic duty is not of course yet to say that it should be a legal duty that the state might enforce: the questions of whether, how far and in what ways the state should exercise its coercive power in this context require more discussion than we can provide here. $)^{31}$

As must be evident, we are not sure how to resolve these issues. We do think, however, that they are worth pursuing not only by moral philosophers, but by legal theorists interested in the proper structure and scope of the criminal law. They bear on the possibility of a more nuanced system of criminal law - one whose core consists of crimes that are "public" in the strong sense that they are to be pursued by "the public", i.e. by the polity, but which also includes wrongs whose pursuit is left more in the hands of, or subject to the will of, their individual victims.

31 But see further S E Marshall, "Victims of crime: their station and its duties", in M Matravers (ed), Managing Modernity: Politics and the Culture of Control (2004) 104. 